\title{
"I left too late, I go back too often": sentiments of belonging and home among Indian scholars in the United Kingdom
}

\author{
Vinicius Kauê Ferreira'
}

'Programa de Pós-Graduação em História Social, Universidade Federal do Rio de Janeiro (PPGHIS-UFRJ), Brasil

\begin{abstract}
This paper addresses current notions of belonging amongst Indian scholars in social sciences building an academic career in the United Kingdom. Drawing on concluded PhD research in social anthropology, it articulates a multi-sited ethnography of centres of research and in-depth interviews. This research project acknowledges the fact that while the literature on circulations of scholars is vast and continues to grow, ethnographic studies on this matter are still rare. For this reason, this paper focuses on an ethnographic comprehension, based on everyday conversations and evocative situations, of these lives that are built in a context of mobility. Here, I address notions of diaspora, global citizenship and cosmopolitanism as relevant hermeneutic tools for the comprehension of transnational sentiments of belonging amongst these scholars. At stake are intersectional elements that include class, gender, origin and caste, in the construction of transnational academic circulations.
\end{abstract}

Key words: mobility, intellectuals, post-coloniality, globalisation, India, United Kingdom. 


\section{"Parti muito tarde, volto com muita frequência": sentimentos de pertença e lar entre pesquisadores indianos no Reino Unido}

\section{Resumo}

Este artigo analisa noções de pertença presentes entre pesquisadores indianos em ciências sociais que buscam construir uma carreira acadêmica no Reino Unido. Baseado nos resultados de uma pesquisa doutoral em antropologia social, o presente texto articula uma etnografia multissituada de centros de pesquisa e entrevistas em profundidade. Apesar da existência de uma vasta e ainda crescente literatura sobre circulações de pesquisadores, raros são os estudos etnográficos sobre o tema. Por esta razão, privilegia-se neste trabalho uma compreensão etnográfica, ancorada em conversas e situações antropologicamente significativas, dessas vidas construídas em contexto de mobilidade. Eu reflito aqui sobre noções de diáspora, cidadania global e cosmopolitismo como conceitos hermeneuticamente relevantes para o estudo da produção transnacional de sentimentos de pertença entre esses acadêmicos. Elementos interseccionais como classe, gênero, origem e casta ocupam aqui um lugar central no debate sobre as circulações transnacionais de acadêmicos.

Palavras-chave: mobilidade, intelectuais, pós-colonialidade, globalização, Índia, Reino Unido. 


\title{
"I left too late, I go back too often": sentiments of belonging and home among Indian scholars in the United Kingdom'
}

\author{
Vinicius Kauê Ferreira
}

Even though he had decided he would walk where the legs lead him, why had he walked all this way within earshot of those bamboo cowbells, that cowherd boy's fluting sounds? Whatever his decision, his feet still walked him close to the habitations of men. This is the limit of his world, his freedom.

(U.R. Ananthamurthy, Samskara: a rite for a dead man, 2012 (1976), p.80)

\section{Introduction: for an ethnography of academic circulations}

June 2015, University of Paris 8, Saint-Denis. With its precarious structure, this university located on the outskirts of Paris, known as a stronghold for migrant students and those of popular origin, hosts the conference of an eminent Indian historian who has made his career between India and the United States. He comes to speak of theories of democracy from a post-colonial point of view, a scene that is less and less rare in French universities, historically refractory to post-colonial criticism, but which still occurs in a geographically and politically marginal institution of Parisian academia. Although my doctoral research concerns the construction of academic trajectories of social scientists ${ }^{2}$ in Europe, I considered this an interesting opportunity to meet an Indian researcher of great recognition abroad. As I would comprehend throughout the course of the research, meeting with researchers established in non-European countries, in addition to the field that I had initially defined in geographic terms, was a fruitful way of putting the initially defined circulation space into perspective.

Once his conference on post-colonial democracies was over, I introduced myself, mentioned my research on 'Indian diasporic scholars' and asked him whether he was available for an interview. He gave me a sceptical look and answered evasively. It then seemed clear to me that he was not interested and I began to wonder whether my approach had been inadequate. This question haunted me for several days until, progressively, and thanks to certain dialogues with colleagues, I began to elaborate it through an image that seemed right to me: that of a kite. While these researchers saw themselves as cosmopolitan people, global citizens flying across the planet, with my proposal to discuss their 'diaspora', I incarnated the boy who pulls the kite string back to India. As I would understand better later, from other interlocutions and field situations, the term diaspora was not welcome among my interlocutors.

In addition to the question of choosing the correct word that provides access to a specific field, this reflection led me to the need to review my research questions, the theoretical framework of my project, as well as the nature of my field. If my project was not about the 'diaspora' of researchers, then what was it about? This question seemed even more difficult to me as a vast literature explored such circulations precisely through this non grata notion (Assayag \& Béneii 2004). This was a fundamental step in the construction of a research problem and which I return to in this article. The analysis specifically proposed here is part of a

\footnotetext{
1 The translation of this article was funded by the Graduate Program in Social History of the Federal University of Rio de Janeiro.

2 By social scientists, I use the European understanding of the term, which includes sociologists, anthropologists, political scientists, historians and specialists in cultural studies.
} 
broader research on the social, cultural and political conditions of constructing an academic life between India and Europe. The fieldwork was carried out between 2015 and 2017, in England, Germany and India, where I conducted participant observation of academic events, institutions and political mobilisations, in addition to about 50 interviews with 50 researchers at different career levels - from post-doctoral students to retired professors -, 30 of them in the United Kingdom, the focus of this article.

I discuss here notions of belonging articulated by Indian researchers in social sciences who have built an academic career in the UK at the present time. More precisely, it is about understanding how the experience of constructing an academic trajectory is meant by Indian social scientists in a context in which a long colonial and post-colonial history is resignified through the lexicon of globalisation and its avatars, such as transnationalism, cosmopolitanism and the diaspora. In this sense, post-colonial studies constitute a privileged theoretical framework in the analysis of these circulations, insofar as they equip us with valuable tools to reflect on how imaginaries, projects and subjectivities are produced by the circulations of people, objects, symbols and ideas within a long colonial history which, although mise à jour, remains largely structured on ancient practices and connections (Hall 1996).

This means that, when put into perspective with reflections on post-coloniality, notions like 'transnationalism' and 'cosmopolitanism', consecrated by the literature on contemporary flows (Hannerz 1997), become categories that must be critically analysed from the point of view of historically unequal power relations that are currently reframed through a lexicon inherent to so-called 'globalisation' (Ferreira 2017a). Even the term globalisation, and its heuristic capacity in the analysis of knowledge production and circulation processes, must be considered from a post-colonial point of view (Krishna 2009). This is because much of the consecrated literature on globalisation disregards the post-colonial nature of these processes (Abélès 2012), not to mention authors who despite weaving relationships between the two, do so in an almost celebratory (Appadurai 1996) or fatalistic manner (Bhabha 1994). In short, the analysis proposed in this article addresses specific dimensions of a broader multi-sited ethnography (Marcus 1995) of academic lives constructed in the context of circulation within a post-colonial space.

In this article, I focus on the narratives of three interlocutors, named Binoy, Irrfan and Tridib ${ }^{3}$, and analyse their trajectories from an anthropological viewpoint (Velho 1986), in order to privilege an articulation between spheres that are deeply constitutive of the latter: from a reflection on family trajectories and social capital, through schooling, and class and caste belonging (Bénéi 2008; Bourdieu 1980; Bourdieu and Passeron 1964, Lahire 1995, Srivastava 1998), up to narratives on circulation and sentiments of belonging in transnational contexts (Hall 1997), without losing sight of the historical background in which these circulations are inscribed and from which the imaginaries and subjectivities that are characteristic of it are produced. I also recover ethnographic situations of collective mobilisation in order to highlight practices of building active connections with India from Europe. At the same time, institutional and epistemological transformations (Bénéi 2005a, Ribeiro and Escobar 2006) play an important role in mapping the landscape in which such trajectories are forged, since the latter are shaped considerably by the institutional architecture of contemporary scientific policies and a certain 'knowledge economy' (Wright 2014, 2016) that characterises the English-speaking academic world in particular. Therefore, the effort consists of composing an ethnographic reflection that articulates history and scientific policies in the construction of subjectivities in the context of academic mobility.

The circulation of Indian scholars between India and Europe is a traditional and well-known dynamic in European academic circles. Although this topic has occupied an important place in the field of intellectual history for many decades (Bayly 1999, Cohn 1996, Lardinois 2007, O'Hanlon 2014, Trautmann 1997), not to mention texts of an autobiographical and hagiographic nature (Assayag and Bénéi 2004, Subrahmanyam 
2015), such circulations have never been the subject of an ethnographic study in which the circulations of researchers were studied in the same methodological, conceptual and axiological terms as other subjects of anthropological interest. While it is true that there is a vast and solid ethnographic production on student circulations (Barros and Adnane 2017, Cicchelli 2012), including that dedicated to Indian students in Europe (Tejada et al. 2014), it must be emphasised that the analysis of circulations of researchers implies some specificities concerning professional projects, trajectories, sociability, family relationships, and scientific policies that are distinct from, albeit related to, those involved in the study of student circulations. Moreover, although it is possible to speak of an important sociology of academic circulations (Garcia 2005) that seeks to restore contemporary processes of mobility, there are few works that conduct an ethnographic approach to academic life guided by participant observation and dense description of events and institutions, or even accompanying interlocutors in their daily experiences.

\section{The figure of the 'Indian intellectual': social and imaginary origins}

A young professor at Cambridge University, Binoy greeted me kindly in his almost ascetically decorated office. On his desk, a bust of Mahatma Gandhi; on the wall just behind him, a photo of three eminent male figures in Indian history, including Rabindranath Tagore, the great writer, poet, composer, philosopher and educator of the turn of the twentieth century in India. This is the first of a series of occasions when I would find references to Tagore and Gandhi in the work spaces of my interlocutors - especially those of the men. Binoy is a young researcher born in the state of Assam, located in north-eastern India, from a family of university professors specialised in English literature and philosophy, who came from different states of India. Although his parents are Hindus, his Christian aunt had an important influence on his religious background, to the point that he identified as a Christian thanks to her. His mother was a practicing Vaishnava (a devotee of Vishnu as the supreme god), while his father, a trained Hindu, always told him that 'his religion was Tagore'. It is precisely through this story of a family interwoven at the crossroads of different religious practices, regional origins, values that are at the same time spiritual and secular, Anglophiles and practitioners of a cosmopolitan Hinduism, often represented in the figures of Tagore and Gandhi, that Binoy interprets his intellectual trajectory and its ethical position in relation to the world. And it is through this set of elements that he speaks of the 'Indian intellectual'.

Binoy's social origins echo the origin of the vast majority of my interlocutors, men and women equally represented, in the United Kingdom: they belong to the middle and upper classes of high caste, intellectual, lightskinned ${ }^{4}$ families, formed in a highly appreciated Anglophilic culture, while proud of a certain cosmopolitan aspect of 'Indian culture'. This was the profile of about $90 \%$ of the researchers I interviewed, and it was no different when it came to his academic background: like many, Binoy had passed through the great institutions that constitute the voie royale of the Indian researcher who finds success in Europe. He graduated from St. Stephen's College, the most renowned college in India, and which was founded-Binoy told me in detail—in 1881 by a British Anglican mission called the Cambridge Mission. In retrieving this history, Binoy demonstrated a precise knowledge that allowed him, above all, to inscribe himself in the history of the most prestigious and elite Indian college, frequently elevated to the role of the nation builder of modern India (Rao 1991, Trivedi 1991), and through which many of my interlocutors in England had passed. Binoy highlighted more than

\footnotetext{
4 The debate on race in India is complex and intersects with caste, gender and regional origin in terms that are quite specific to the Indian context. However, it is widely recognised that "fair" skin is socially associated with high castes, while "dark" skin is associated with lower castes and Dalits (those who are theoretically excluded from the caste system) (Beteille 1990). Recent literature on the consumption of whitening cosmetics in India has been important to understanding the social value of whiteness as a standard of social status (Srivastava 2013).
} 
once that not only was this institution created according to Cambridge models, but also that this link persists, insofar as the majority of St. Stephen's teachers are still trained in Cambridge. It is not for nothing that he, like others of my Indian interlocutors, claimed to feel a certain familiarity with Cambridge even before moving on to his post-graduate studies: 'St. Stephen's College fits Cambridge perfectly', he said.

This Anglophile education was as present in the school environment as in the sphere of the home. As young students, they developed great familiarity with certain spheres of British and American culture, especially their respective expressions of classic and modern art and lifestyle. The main references to the United Kingdom revolved around the English language, classical literature and, of course, academic references, while the United States provided a more 'modern' repertoire, including certain musical styles (such as jazz and rock), certain food culture and consumer goods 5 . In this context, leaving for the UK to continue their studies was often conveyed as an unplanned step and rarely engendered deep feelings of academic or cultural displacement. On the contrary, the 'premier institutions' they had passed through 'fit' perfectly in renowned British institutions. As one of my Cambridge-based interlocutors would say, 'after passing through St. Stephen's College, continuing your studies at Cambridge is an almost natural step'.

Evidently, this is not the case for the every one of my interlocutors. Some of them of more modest origin, had passed through less elite institutions and were critics of the dominant figures mentioned by Binoy, such as Gandhi and Tagore, as symbols of cosmopolitanism and the very archetype of the 'Indian intellectual'. In this context, the figure of B.R. Ambedkar, a Dalit intellectual and political opponent of Gandhi ${ }^{6}$, has been revived as a symbol of a non-Brahmin intellectuality, given that the first two, although critical of the practices of 'untouchability', are among the Hindus and Brahmins that compose the pantheon of Indian national heroes. However, it is not an exaggeration to underline that this is a recent movement with expression in less traditional academic networks than those that lead to universities like Cambridge and Oxford. Binoy's trajectory is quite representative of the general and incredibly homogeneous profile of my interlocutors in England?

In the main, the narratives articulated by Indian social scientists employed at European universities ${ }^{8}$ reveal extraordinarily similar academic and family structures. These are women and men born into families of middle and upper classes ${ }^{9}$ and castes, to parents employed in positions of relative or high social prestige. Among the researchers I was able to interview in the United Kingdom, at least half are children of civil servants, for example, which in India is not only a relatively well-regarded occupation, but above all a strategic social position in terms of access to material and symbolic resources. Others are the children of doctors, diplomats, university or secondary teachers (usually the mother) or private sector employees in commanding positions. In addition, it is easy to perceive how their families, through their brothers, uncles and other close relatives,

\footnotetext{
5 The USA has emerged as a cultural reference with greater force since the 199os, when it marked the economic liberalisation of India. Before that, under the preponderance of the Nehruvian development project, more closely related to soft socialism, there was significant resistance to cultural products and consumer goods that referred to the US. Representative of this is the famous ban on Coca-Cola by the Indian government in 1977 , which lasted 16 years.

6 Ambedkar, an intellectual of Dalit origin, then known as untouchable, was especially opposed to Gandhi in the debate about the caste system and Hinduism. In this regard, see his text entitled "What Congress and Gandhi have done to the Untouchables" (1945). For a more comprehensive reading of his ideas, see his work "The Annihilation of Caste" (1936).

7 The profile of Indian students in England is certainly more diverse thanks to ongoing changes in the funding policies that structure these circulations, especially through scholarships programmes. When it comes to permanent teaching positions, however, the latter are still mostly occupied by scholars of wealthy backgrounds.

8 As is widely known nowadays, working conditions in European academic institutions are increasingly precarious, mainly due to the expansion of temporary teaching and research contracts. Despite being an important point of reflection for this research, having been the object of analysis in another publication (Ferreira 2017a), it will not be possible to address it in detail in this article. Here I deal specifically with the trajectories narrated by researchers employed in permanent positions in research and teaching institutions in the United Kingdom.

9 It is important to emphasise that the term middle-class does not have the same meaning in India as it does in many European countries. If, in the latter, this category usually refers to part of the working class, in the Indian subcontinent, as well as in many countries of the global South, it mostly concerns much more restricted and privileged groups in terms of access to financial resources and symbolic capital (Fernandes 2006).
} 
extend into different professions, including: public service, military careers, political positions, international institutions, financial institutions, engineering, and technology companies. Equally relevant is the fact that these family networks extend beyond India, thanks to relatives (uncles, cousins, close friends, etc.) who live or have lived in Europe at some point. In other words, participating in such a diverse, extensive and prestigious network exponentially reinforces the social capital necessary to access certain intellectual spheres both in India and in Europe.

Intranational or regional migration also seems to be a constituent element of my interlocutors' recent family trajectories, as occurred in Binoy's family, where it was not uncommon for the parents or grandparents to have migrated regionally, within the Indian subcontinent itself. If, on the one hand, this is a relatively common narrative in South Asia - since the history of the region is marked by numerous processes of displacement and migration -, in the case of these intellectuals, such narratives become a key element in claiming the essentially cosmopolitan nature of their personal and intellectual development: their personal and family histories are presented as stories of continuous displacement and linguistic and religious syncretism that accompanies such circulations. As a result of this family mobility, so common to the Indian researchers I met, Binoy speaks five languages: Assamese, Hindi, Bengali, Urdu, and English. These are the languages he learned at school (Assamese, the official language of the state Assam, and the national languages Hindi and English ${ }^{10}$ ), spoke at home (Assamese and English), in addition to those learned informally with friends in Assam and later in Delhi (Bengali and Urdu, respectively).

This, incidentally, is a key element widely shared among these researchers: India is a cosmopolitan space par excellence. According to this narrative, the great Indian metropolises, such as Delhi, Kolkata, Mumbai and Chennai, represent an eminently cosmopolitan national landscape, since these urban spaces embody the cultural, linguistic and history diversity that characterises the country. In this sense, these are described as highly modern, intellectualised and culturally vibrant cities, located at points of intersection of the intense circulations that mark Indian society: ideal places for the production of cosmopolitan intellectuals, as also shown by Sanjay Srivastava (1996). It is no wonder that almost all of my interlocutors who grew up in smaller cities, moved to Kolkata, Mumbai or, especially, Delhi for their undergraduate or post-graduate studies. Many of them used the expression 'eye-opener' to refer to the experience of moving to these cities: it was a movement to expand cultural repertoires, perspectives on the world and knowledge about the very cosmopolitanism that characterises India.

This cosmopolitanism is expressed in the progressive stance of their families, essentially modern in terms of morals, politically liberal and 'secularised', which means that they do not subscribe to conservative forms of Hinduism expressed in the Hindutva movement ${ }^{11}$. Given this context, my female interlocutors reported relative freedom concerning how they could plan their futures, having been encouraged to study and travel, and having been pressured to marry far less than other women close to them were.

Thus, like Binoy, almost all of these researchers went through the same restricted group of prestigious higher education institutions in India, and later in the United Kingdom or the United States (particularly Ivy League institutions), revealing a kind of layered funnelling system that represents the select 'premier institutions'. Therefore, not being accepted at a certain stage of their development into such institutions represents a serious setback in the very important project of maintaining their social position (rarely social ascension) that marks these trajectories. In this context, family expectations about these young people gravitates particularly towards

\footnotetext{
10 In general, language teaching in Indian schools is structured in the following triad: the official regional language of each state (from among the 27 official regional languages), English and Hindi.

11 The Hindutva movement is characterised by its essentially anti-Muslim nationalist religious ideas and is associated with the far-right Bharatiya Janata Party, BJP (literal translation: the Indian People's Party). For an analysis of the movement's history, its symbols and the place of women in its structure and symbology, see Paola Bacchetta (1994 and 2005).
} 
professions like medicine, engineering, technology, or well-paid positions in the private or public sector, but they also turn to the social prestige linked to certain educational institutions at all levels, even though the traditional respect associated with the profession of university professor is in sharp decline.

Indeed, for many middle and upper class Indian families, the academic career is not as desirable as it has been in the recent past, due not only to precarious wages and working conditions, but also to the profession's loss of prestige. Even though many of my interlocutors argue that salaries for permanent positions are not dissatisfactory in higher education, especially in some private institutions, it is clear that the prestige associated with this profession has declined. Susan Bayly (2007) is quite assertive when relating this drop in the prestige of the academic career in the country, which from the 199os onwards began to be seen as 'unrewarding', to the implementation of positive discrimination policies in order to guarantee the access of low caste students and teachers to university. For a large part of the Indian middle classes, argues Bayly, such policies are the denial of the most fundamental meritocratic principle that should govern academic work ${ }^{12}$. Even though this seems to be a very distant position from that adopted by the vast majority of my interlocutors, more aligned with the fight against the caste system, such factors cannot be ignored in the consolidation of social representations that inform family expectations.

Thus, it is common to hear from my interlocutors that they were able to assert their choices for the humanities - and for an academic career - because they were accepted in the most prestigious institutions in Delhi, Kolkata or Mumbai. This can often end up being a strong argument in family negotiations: 'If you want to study history, you must do it at St. Stephen's College', as one of my interlocutors, currently a professor in the north of England, heard from his father.

\section{Mobility and sentiments of belonging}

With this background in mind, I would like to focus on my fieldwork in the UK in order to explore representations and sentiments of belonging that are proper to this given context of circulations. Which elements are articulated in the everyday production of meaning for their own trajectories in the context of intense - and often indefinite - geographical mobility? As I intend to show, the narratives in question raise very particular understandings of terms like cosmopolitanism, global citizen and diaspora that need to be carefully analysed. In addition, I try to sustain that such trajectories mobilise certain strategies of production of belonging that are quite specific to academic life in the context of scientific circulation policies, although practices quite common to non-academic migration also carry great weight in scientific circulations.

Even though many of my interlocutors had never visited the United Kingdom before (indeed, most had never even travelled outside India), their arrival in the United Kingdom was described by feelings of 'familiarity'. Those who mentioned difficulties with adaptation raised relatively banal everyday problems (like the use of a laundry), alongside certain more important factors (such as food practices, distance from their family and the climate); however, even the latter did not seem to imply any sense of deep unsettlement, much less rupture, on the subjective plane. All described processes of swift local adaptation and integration with research centres and groups of friends. Apparently, their intellectual development underwent familiarisation at a distance with the English academic and cultural context, especially British and American.

However, this does not mean that their subjective establishment in the United Kingdom - that is, the consolidation of ties, sentiments of belonging and sense of home - was a less complex process. Although the set of historical and cultural connections that engender the sharing of stories, values, projects and models are

12 For a detailed analysis of the decline in the prestige of the academic profession in South Asia, see the report resulting from research coordinated by Partha Chatterjee (2002). 
quite real, notably for the more well-educated Indian strata, contributing to the production of very Anglophile identities, these same connections are also a source of complex sentiments that require meticulous analysis.

During one interview with a US-based professor who was spending a sabbatical year in Cambridge, I heard that 'being in Cambridge is different, here even the street names tell us something'. Indeed, street names, institutions, architecture, libraries, the city as whole seem to compose a landscape of relatively familiar and meaningful imaginary for these newcomer Indian students and researchers. An interesting sense of belonging can be glimpsed, for these spaces 'make sense' to them, allowing them to situate themselves within a long historical narrative that articulates both Indian and British territories in the construction of a transnational trajectory. Seen from another perspective - and subscribing to a necessary criticism of methodological nationalism (Peirano 2004) -, this speaks to a continuous, transnational, historical, and epistemological space, within which such projects and subjectivities are forged.

On the other hand, these continuities do not translate into simple settlement processes. Decidedly more complex, their lives are built on a continuous circulation between the new country and an alleged 'land of origin' (to use one of the many botanical analogies that constitute the semantic field of belonging ${ }^{13}$ ). The reasons generally listed for this are mainly two-fold: family and academic work. Regarding family ties, many opted for the United Kingdom rather than the United States due to the closer proximity to India ${ }^{14}$. Concerning academic travels, almost all of them work in India and usually go on research trips and, in some cases, to participate in events. Visits are made once or twice a year and occasionally - when receiving a year-long sabbatical, for example - the stay may extend for months.

However, it is not uncommon for their narratives to minimise the weight of these affective and professional connections in their daily lives, even though important references to India are frequently found in their offices, such as a bust of Mahatma Gandhi, images or writings of the poet Tagore on the walls, religious images, not to mention dozens of books on South Asia or even the fact that many are married to Indian partners. A certain attitude of minimising the weight of daily and affective ties tends to serve as a line that differentiates these scholars from those who harbour 'nationalist' feelings, which they describe as being excessively attached to identity-oriented discourses that they consider incompatible with the type of people they consider themselves to be. For themselves, they claim the status of 'global citizens'.

\section{Cosmopolitanism and global citizenship: diaspora and political engagements}

Irrfan welcomes me to his office at the School of Oriental and African Studies (SOAS) of the University of London. Founded in 1916, initially named the School of African Studies, the institution was conceived as part of a new strategy of the exercise of soft power of the then British empire over its colonies: the SOAS was the cornerstone of a policy of 'academic hospitality' (Bénéi 2005a: 65), which consisted of the active enticement of children of the elites from the colonies to be trained in the metropolis, who then returned to their countries. In the context of the eminent collapse of the empire, due to the growing strength of the movements for independence in Africa and Asia, the United Kingdom adopted a new strategy to guarantee influence over local elites: university studies on South Asia and intellectual training of young people within British models thus became a central geopolitical issue. It is not by chance that in 1936-37, the 174 foreign students at SOAS represented $40 \%$ of the enrollees, while in 1960-61, they made up 81\% (Philips 1967).

\footnotetext{
13 For an interesting analysis of the use of botanical terms (like soil, genealogical tree, roots, culture) and their implications for the definition of anthropological terms, such as culture and native, see Liisa Malkki (1992).

14 Very similar arguments have a privileged place in narratives involving much more recent circulations among some academics with whom I was able to talk, and who have been working in the Middle East and South Asia, often in branches of American and British institutions recently opened in these places.
} 
Today, the SOAS is a vibrant institution that welcomes students from different parts of the world, with different trajectories and with very active political lives. More than a mere site to train in Asian and African languages and culture, it has become a space for the affirmation of the intellectual cosmopolitanism that my interlocutors speak about. Here are taught not only young people from different parts of the world, but also the children of the Indian diaspora (among numerous others) established in the United Kingdom (Bénéi 2005b). An internationalised, global institution that, like other British institutions, began only recently to hire international teachers to attract international students. In the last decade, this notion of cosmopolitanism has extended to the recruitment policies of several British and European institutions, and the presence of Irrfan and many of my interlocutors form part of this movement.

Irrfan's office is small, simply decorated, with a table, two chairs and a pair of shelves attached to the walls. Among the books arranged on the table and on the windowsill, I see works by Edward Saïd and Paul Ricoeur. $\mathrm{He}$ is a very kind and considerate man in his forties. As soon as I enter, he says that he was waiting for me, showing a sincere interest in my research, which seems evident to me since he works on cosmopolitanism and political engagements. Irrfan was born in Bangalore, into a middle class family: his father is an engineer and his mother is a secondary school teacher. Like Binoy, he studied at an English-medium school, founded and run by a Christian mission ${ }^{15}$, with very traditional methods, minimally political, and eminently middle and upper class. As with all my interlocutors, caste was not an issue brought up when talking about social origins, since this is a very delicate topic and remains in a kind of unspoken ambiguity. However, Indian surnames are directly associated with specific castes, and Irrfan's surname is a common Brahmin surname from South India. And my conversation with Irrfan was very revealing of what these 'cosmopolitan' scholars understand by 'diaspora' and their own relationship with the term.

As I described at the beginning of the article, the notion of 'diaspora' had gained relative centrality in my research precisely because of the resistance I had observed to the term, but for some time, the heuristic implications of that were not entirely clear to me. My conversation with Irrfan led us to a discussion about the term, in which I asked him whether he recognised himself as a diasporic subject, to which he replied: 'I don't feel in diaspora. I left too late and I go back too often'.

Most of my interlocutors strongly refute the idea of diaspora as a descriptive term for their trajectories, since 'diasporic' is equated with 'identity', 'essentialism', 'patriotic exile' or even 'ghetto' sociability ${ }^{16}$. This representation of 'the Indian diaspora', especially its British version, essentially refers to the first and second generation of India-origin communities united around Hindu nationalist feelings, marked by political and cultural conservatism, with high doses of anti-Muslim tendencies. Right-wing nationalist movements, based on a certain form of religious revivalism, have defined contemporary political life not only in India, but also among its so-called 'diaspora', which has increasingly been the subject of much attention by the current rightwing Indian government ${ }^{17}$. It is not by chance that official statuses, such as Non-Resident Indians (NRI) and Person of Indian Origin (POI), have been coined by the Indian government in order to create and strengthen policies specifically aimed at these groups in the project of transnational construction of a Hindu nationalism.

Therefore, among my interlocutors, what is at stake is the opposition to such feelings, sociabilities and political positions that, in their eyes, reproduce nationalist narratives. For these researchers, this distance traverses the refutation of the notion of diaspora. Also emphasised is the fact that they participate in local and international networks and spaces of sociability, which do not traverse the 'Indian community'.

\footnotetext{
15 Many of my interlocutors studied in Catholic school; however, that does not mean that they come from Catholic families or they have converted to Catholicism. In India, confessional schools are a highly sought-after alternative to ensure quality education at reasonable, sometimes modicum, cost, especially in the case of families with many children.

16 Positions like this are expressed in texts published by Indian researchers, like in Sanjay Subrahmanyam (2015).

17 For an in-depth debate on the articulation between nationalisms and religion in South Asia and Europe, see van der Veer and Lehmann (1999)
} 
For some, the simple question about the significance of the term diaspora to describe their own trajectories may sound slightly offensive, for others, just meaningless. They argue that they do not participate in social events defined by their ethnic nature, they do not live in Indian neighbourhoods, they do not participate in festivities like Holi or Diwali, nor are they attached to religious traditions that generally constitute such 'communities'. Apparently, one cannot be in diaspora and occupy the position of a global citizen at the same time.

Irrfan's statement is especially potent, meaningful, insofar as it speaks in a very synthetic, but incisive, manner about a fundamental feature of a hermeneutically fertile notion of diaspora amid a rather unfortunate proliferation of meanings - and, therefore, lack of them - attributed to the term in recent years ${ }^{18}$. Khachig Tölölyam $(2005,2007)$ has developed an argument that is certainly plausible when contesting the idea, overly disseminated by a vast literature, that diasporas concern the circulation of people. He argues that in most contexts, 'diaspora' describes settlement processes.

If we assume, following Tölölyam, that diasporas are produced by settlement processes, then their strength lies in their ability to circulate goods, imaginaries, nationalisms, money and films, while the real and intense circulation of people is reserved for restricted groups of people who have the financial resources for that. This is not to say that Indian persons or those of Indian origin living in countries like the United Kingdom, the United States or Australia do not organise visits to India; indeed, this is a popular practice among Indian diasporic communities. However, it is necessary to bear in mind that these are normally activities undertaken by families that have the financial and symbolic capital for this purpose ${ }^{19}$. Diasporic identity is then much more related to the construction of imaginaries about a land left behind, of a belonging nurtured at a distance.

That said, it can be argued that social and political positionalities are determinant in the adherence, or lack thereof, to the notion of diaspora. Additionally, social class plays a dual role ${ }^{20}$. First, the idea of cosmopolitanism, of 'global citizenship', is presented as the stamp of an education in which the project of an international life is inscribed within a vast 'field of possibilities' (Velho 1986) presented to these individuals from privileged groups. Second, it is class that allows such individuals to see themselves as global citizens, to the extent that, as 'privileged migrants' (Croucher 2012), their geographical and institutional circulation is facilitated, even though their class status does not exempt them from migratory complications inherent to post-colonial circulations between metropolises and former colonies. As one of my interlocutors, who is dedicated to reflections on diaspora and cosmopolitanism, would say, it was their class privileges - a class of 'global intellectuals' - that allowed them to 'not be diasporic' precisely because they did not need to rely on local diasporic communities ${ }^{21}$.

This researcher strongly criticised those academics who are resistant to the term diaspora. He not only claimed this category to designate his own trajectory, but he also accused these others of being 'elitist', unable to recognise the class privileges that allow them to claim an abstract, uprooted global citizenship. This interlocutor was much more open to talking about the ways in which he nurtured emotional ties with India through symbols that inhabit his youthful memories: certain brands of frozen food, soft drinks, musical genres, etc. Like the other scholars I met, he does not live in an 'Indian neighbourhood', nor does he participate in particularly 'Indian' sociabilities. However, in his discourse, he approaches an understanding of diaspora that is closer to that proposed by James Clifford (1994): a transnational space through which imaginaries can

\footnotetext{
18 For a debate on the uses and abuses of the term 'diaspora', see Tölölyan (2007) and Brubaker (2005).

19 In line with this, it is important to keep in mind that a large part of the Indian diaspora occurs within the framework of policies to attract highly qualified professionals to the USA and the UK, using special visas for such professionals, especially in the technology sector. This means that the Indian community in these countries is often a diaspora of the middle and upper class, as shown by Jackie Assayag and Véronique Bénéi (2005) and David Washbrook (2013).

20 By class, I refer to a marker defined mainly by the possession of certain types of social capital and the incorporation of a certain lifestyle (Bourdieu and Saint-Martin 1976), in which money has an important weight but is not a qualifying or, on occasion, even a necessary condition.

21 I develop this argument in greater detail in another publication (Ferreira 2017b)
} 
circulate and be shared among people established in different parts of the planet. However, even this definition remains not only vast and imprecise, but does not take into account the diversity of meanings and vernacular understandings of the diaspora ${ }^{22}$.

For the most part, the narrative articulated in the interpretation of a life in which circulation acquires an encompassing dimension of its projects - and which also occurs between institutions and countries throughout their careers - favours ideas like cosmopolitanism and global citizenship. These ideas evoke the image of a person detached from national borders and national cultural identities. However, what is at stake here is the notion that leaving for the United Kingdom clearly expresses an eminently cosmopolitan tendency characteristic of so-called global citizenship. Thus, if the Indian intellectual is a cosmopolitan intellectual par excellence, the United Kingdom is 'the world' par excellence. Leaving for the United Kingdom - this space which in a certain historically and epistemologically sense overlaps that of India - is leaving for 'the world'. Thus, the United Kingdom not only transcends the status of 'locality', but also erases the post-colonial connections that engender such circulations as contemporary intellectuals progressively detach themselves from the postcolonial lexicon to forge themselves in another, now global, lexicon.

What is interesting here is the very peculiar relationship that is produced between the local and the global, because it is based on a double assertion. On the one hand, the local appears as global because, as stated above, India is evoked as a cosmopolitan place par excellence $e^{23}$. On the other hand, the location that is so important in the modern history of India, the United Kingdom, is equated with 'the world'. Together, India and the United Kingdom constitute an eminently 'global' circulation space, as they are both connected and cosmopolitan locations. Even though new circulations have emerged - not only to the USA, already a traditional destination, but also Australia, Latin America, Africa, the Middle East and other European countries ${ }^{24}$ - the United Kingdom continues to occupy a privileged space in the imaginary of Indian academics.

\section{Engaging from Europe: the transnational construction of identities}

The evening of November 9, 2015. The classroom at King's College, Cambridge, is packed with researchers and students. Some of them are looking for a place to stand at the door, because the space cannot accommodate the approximately 70 people who participate in the discussion. They are mainly Indian academics or Indianists, from students to senior professors, gathered to express their opposition to what they consider unacceptable news: as part of an official visit by Indian Prime Minister Narendra Modi to the United Kingdom, the University of Cambridge had invited this highly controversial far-right politician to deliver a talk at the university. Shortly after the first rumours about this invitation spread through college hallways, a few weeks before Modi's arrival, Indianists and Indian researchers from several countries signed a public letter addressed to the university administration, expressing their concern about the possible 'disrepute' that such an official invitation could provoke for the institution. Even before the university's invitation, several demonstrations were organised by a large number of associations and political groups opposed to the prime minister and his party. All that remains is the prospect of a formal and celebrated alliance between the university and a far-right Indian government, accused of attacks on freedom of expression and promoting religious intolerance, which triggered the joint mobilisation of Indian scholars based abroad.

\footnotetext{
22 A positivised, alternative understanding of the notion in question is developed by one of my interlocutors, who speaks about the diaspora as an ethical position. I will not be able to address this here, but it is well represented in an article published by Dibyesh Anand (2009).

23 Some Indian researchers subscribe to the controversial perspective that British colonisation was the historical fact responsible for the insertion of India in a true process of globalisation (Roy 2000).

24 I have also established dialogues with researchers in countries in the Middle East. On the contemporary circulation of Indian university professors in Africa, particularly in Ethiopia, see Thubauville (2013).
} 
Entitled Let's Talk Modi, the meeting was organised by the Cambridge Action association and was presented on its Facebook page as a 'University-wide discussion on the attacks on academic freedom, privatisation of education and rising tide of intolerance in India'. Among the speakers were three professors and a student, a member of the South Asian Solidarity Group, known for organising debates on freedom of expression and equality in South Asia. The purpose of the meeting, announced by one of the organisers, was to discuss concrete actions that could persuade the university to withdraw the controversial invitation. Speakers included students and university professors, all Indian, who spoke briefly before an animated debate with the public. The debate, in which a large number of people participated, focused on two fundamental aspects: (a) the perception that the BJP, Narendra Modi's party, and its socio-religious movement RSS, not only promote violence against non-Hindu beliefs and religions, but also against lower castes and other marginalised groups in India; and (b) the reason why the University of Cambridge was interested in promoting close ties with this government, despite the fact that, in the very recent past, the political leader was the centre of a diplomatic imbroglio between these two countries ${ }^{25}$.

Among those present in the debate, it was widely agreed that the invitation to Modi was linked to strategies to attract Indian students and funding to the University: in the second decade of the twenty-first century, British universities began to receive significant sums of money from the state and Indian companies to found research centres, chairs and scholarship funding. Mobilisations against Modi's visit proliferated in the days leading up to his arrival, all organised by associations for the defence of human rights, political freedom, and economic development in South Asia. Finally, amid dinners with Prime Minister David Cameron, lunches with Queen Elizabeth, and business meetings with local tycoons, the University of Cambridge eventually cancelled the invitation, bowing to pressure from researchers from different parts of the world.

These events reveal how apparently separate dimensions, that is, diplomatic matters of the Indian government and the academic life of Indian researchers in the United Kingdom, are intertwined not only in the construction of knowledge geopolitics by institutions, but also in processes of the formation of subjectivities, trajectories and narratives of these individuals. It is evident here how official politics, political commitment, and sentiments of belonging take on an increasingly transnational dimension, while playing a central role in the constitution of self-representations among Indian researchers based in Europe. Seen from an ethnographic point of view, the question here is understanding how researchers negotiate sentiments of belonging and political commitment within a transnational social space; in other words, what kind of ethical and subjective relationship can be built with India from the United Kingdom? A central question is that the notion of 'getting involved with India in Europe' is widely shared by the younger generations when identifying themselves as 'global citizens', whereas for the generations who studied abroad up to the 199os, political involvement with India was essentially associated with returning home based on the desire to contribute to the development of post-independence India. As I show in the following pages, a more recent movement has resignified this political bond with India by staying in Europe. These 'global citizens' are inscribed in a changing global academic context in relation to those who have returned in the past, either by choice or for lack of opportunities.

Installed in his office, a poem by Rabindranath Tagore fixed on the wall behind him, Tridib, who teaches history at a university in the north of England, speaks enthusiastically of his thesis in history defended at the University of London. A very political issue, indeed controversial, that expresses his ethical involvement with India. Tridib, who is married to a researcher in another area of knowledge, gave a very particular account of his academic trajectory when compared with other male interlocutors: he credited the choices of his professional life to the desire to follow his wife, thanks to whom, says Tridib, he would eventually become a researcher.

25 In 2002, as the Chief Minister of the state of Maharashtra, Narendra Modi was accused of deliberately not taking action to stop a series of anti-Muslim riots. As a result, more than 1,00o people died and a travel ban was imposed on him by the US and the UK until 2012, when the diplomatic boycott was ended as his popularity grew not only in India, but also amongst the influential Indian diaspora present in these countries. 
After meeting during their undergraduate studies at St. Stephen's College and pursuing a master's degree at the prestigious Jawaharlal Nehru University in New Delhi, the two left to pursue their doctoral studies in different cities in England. Having been raised by his grandfather, a diplomat, he spent most of his childhood and adolescence living in different countries (West Germany, Cambodia and Bangladesh), and returned to live in India only during his secondary education. Like many of my interlocutors, Tridib describes his Indian school as an excellent school, but 'not an elite one': a private school, eminently English-speaking, which had many places for the children of well-placed civil servants who held positions of high mobility.

During our conversation, I ask him if they planned to return to India at any time - which is, in fact, an issue for some -, to which he responded by evoking questions of a political nature:

But at least in my family I was the first person who married a non-Bengali, and in her family too, the first person who married a non-Punjabi. So, there was a rebellion going on there. [...] So those connections remain, but the only tension that my wife and I now feel is that there is now a younger generation from the families willing to... that is coming up. That is actually quite right-wing, it's very middle class, right-wing politics, where the politics of aspiration and ambition, these are now buzzwords for the current right-wing government. Which we are very, very uncomfortable with, because if it was just aspirational perhaps it would have been okay, but this aspiration combined with blaming the other, or creating a very simplistic definition of what it is to be a Hindu, or what it is to be an Indian, that is now creating tensions for us. But again, we feel in our social media blogs, we feel that we can be much more critical sitting here, than we could be from there. And I think it's certainly true that, I think, people notice what we're saying, our criticism from here, much more because [of] what we do here, than if we had been teaching in a small undergraduate college in Delhi.

Tridib, like many of my interlocutors, evokes the idea that being in Europe allows him to engage politically, critically and freely with Indian society in a context of growing political and religious tensions promoted by the far-right government currently in power in India. He refers to the recent advances of the religious nationalist right in the construction of a nationalist history, centred on narratives that essentialise Hinduism as a constitutive trait of Indian national identity. Such processes have acquired considerable dimension within Indian universities, through professors aligned with these political currents that support a certain type of anti-Muslim historical revisionism ${ }^{26}$, and even through the persecution of professors who express dissenting opinions or contest orthodox readings of texts considered sacred ${ }^{27}$. More recently, between the end of 2015 and the beginning of 2016, much attention was paid to cases of casteism (Kumar 2016) and attacks on political and academic freedom at the University of Hyderabad and Jawaharlal Nehru University, two of the main bastions of higher education in the country.

Faced with this situation, many academics based in the country and abroad have positioned themselves theoretically and academically by means of open letters ${ }^{28}$, interviews ${ }^{29}$ and articles (Datta 2016; Sharma 2016).

26 An interesting case is the attempt by Indian historians to prove that the Taj Mahal, widely recognised as a construction from the Mogul period, was erected by Hindu dynasties. See 'How the Taj Mahal became part of the campaign to erase India's Muslim past', Scroll.in, November 12, 2015. Available at: http://scroll.in/article/767712/how-the-taj-mahal-became-part-of-the-campaign-to-erase-indias-muslim-past. Attacks like this have been commonplace in the active work of erasing Muslim history in India.

27 See 'JNU row: SAR Geelani arrested, sent to two-day police custody', Indian Express, February 29, 2016; 'Mysuru professor arrested for "insulting” Lord Rama', Indian Express, June 19, 2016; 'Dalit Professor Arrested For “Insulting” Ram and Modi: Here's What You Should Know About Him', India Resists, June 21, 2016.

28 Some of the international institutions that have written letters denouncing such attacks are: the Centre for Modern Indian Studies (CeMIS, University of Göttingen, Germany); the University of Warwick (United Kingdom); and a letter written jointly by eight British institutions, namely: the Centre for South Asian Studies, University of Cambridge; the Contemporary South Asian Studies Programme, School of Interdisciplinary Area Studies (SIAS), University of Oxford; the South Asia Institute (SOAS), University of London; the Centre for South Asian Studies, University of Edinburgh; the King's India Institute, King's College London; the Gender Institute, London School of Economics; the Institute of Asia and Pacific Studies, University of Nottingham; and the School of International Development, University of East Anglia. This list is not exhaustive.

29 Amartya Sen, Nobel Laureate in Economics, was one of them: 'Amartya Sen Attacks Modi Government For "Extraordinarily Large" Interference In Academia', HuffPost India, July 72015. 
The great majority of these scholars consider that being in Europe allows them to remain freely active in the debates on the paths that India has taken in its national project. Somehow, being outside the Indian academic system appears as a form of possible autonomous, unrestricted engagement with India. In fact, many of them, especially among those who share this argument, publish prolifically on political issues, especially linked to issues of economic development projects, foreign relations and public policies in various fields. This political engagement is underlined in their narratives, and they are often not restricted to publications of an essentially theoretical nature, but end up being transposed to public debates and participation in political demonstrations, as I was able to witness during my fieldwork.

In short, I would like to suggest that, beyond an expression of simple affective attachment, these political manifestations need to be considered in terms of political performativity and the production of collective identities forged abroad. In other words, it is necessary to mobilise an anthropology of politics here in order to better understand the construction of mobilisations around political projects and, above all, a transnational construction of progressive mobilisations in the face of the transnationalisation of deeply conservative nationalist projects.

\section{Post-colonial identities?}

There seems to be the assertion of histories and subjectivities produced in an overlapping space between India and the United Kingdom: not only do Indian institutions 'fit' British institutions and forge highly Anglophone subjectivities, but British history, in its imperial-national construction, is also inseparable from the history of the Indian subcontinent. In this regard, when dealing with subjectivities forged in colonial power relations, Stuart Hall (1997) recalls that there is no British cultural identity without India, after all, its great modern symbol, tea, has always been cultivated on the subcontinent:

Where does it come from? Ceylon/Sri Lanka, India. That is the outside history that is inside the history of the English. There is no English history without that other history. The notion that identity has to do with people that look the same, feel the same, call themselves the same, is nonsense. As a process, as a narrative, as a discourse, it is always told from the position of the Other.

What is more is that identity is always in part a narrative, always in part a kind of representation. It is always within representation. Identity is not something which is formed outside and then we tell stories about it. It is that which is narrated in one's own self. (Hall 1997: 49)

What Hall says about the notion of identity in the context of post-colonial circulations is absolutely fundamental for overcoming quite current essentialist conceptions about the trajectories in question. It helps us shed the necessary critical light, for example, on accusations made since at least the 199os by North Atlantic intellectuals against Indian researchers who left for Europe and the United States in order to pursue an academic career. Such criticisms mobilise unflattering expressions, as Jackie Assayag and Véronique Bénéï remind us:

Briefly, these criticisms range from a way of resisting European hegemony that is none the less expressed in European concepts and terminology (Sahlins) to an elitist endeavour to fit oneself up with the a transdisciplinary niche within the Anglophone academic system (Ahmad 1995; Robbins 1993: chap. 5 \& 6); a comprador bourgeoisie of Western style and educational background, composed of a group of intellectuals who play a mediating role in trading the cultural merchandise of global capitalism in and for the periphery (Appiah 1992: 149); a legitimation, on the academic stage of 'globalisation', of globalised thinkers (Friedman 1999) [...] (Assayag and Bénéi 2004: 18) 
If we want to elaborate an anthropological reflection on production in the academic field, we can affirm that the problem with these criticisms - professedly based on theoretical reflections - is that they do not consider the complexity and peculiarities of post-colonial circulations, which also provide the necessary material for the production of identities from different parts of the world. Moreover, this principle applies not only to India and Indian intellectuals, but to any region of the globe - such as Latin America and its 'westernisation' project (Mignolo 1995) -, including Europe. Believing that such intellectuals are 'westernised' is not just a primary theoretical essentialism that has as its object 'the Indian' - should the 'native' remain caged in 'a culture' and territory, both in the singular, arbitrarily attributed to them? -, while also essentialising, and therefore ethnocentric, concerning what 'the Westerner' is.

I stress, Hall reminds us that there is no Europe, there is no European identity, detached from the colonial and post-colonial circulations that are a constitutive part of their histories and identities. The understanding of identity production in a post-colonial world - and, for some authors, post-imperial (Ribeiro 2008) - cannot be restricted to terms like fragmentation and hybridism in the description of individuals who are supposedly "more post-colonial" than others - that is, more fragmented and hybrid than others (Bhabha 1994), produced at the interstices of disjunction zones -, while others - such as a young man born to a bourgeois family in Paris, student of French philosophy at the École Normale Supérieure - were apparently more unified in their cultural identities and subjective understandings of existence in the social world. If we subscribe to such principles, we run the risk of believing in the existence of a kind of raw cultural material (as if 'purer' is associated with metropolises) that is used in the construction of hybrid identities (as if these were species of cultural paraphernalia, associated with the colonies).

With that, it is not my intention to deny that identities forged within old colonies are traversed by ambivalences, ambiguities or even conflicts that can be difficult to overcome. Authors like Gloria Anzaldúa are a powerful example of how identities can be constructed in complex frontier spaces ${ }^{30}$, which individuals born in hegemonic social spaces probably do not know until later in life or indirectly. To paraphrase Hall again, at the present moment when the margins begin to occupy the centres (movements of black youth in London, of migrants from Maghreb in Paris, etc.) everyone begins to feel like they have migrated. What we need to question is the naturalisation of the apparent homogeneity of national identities, especially nowadays, when a post-colonial critique has widely shown that national identities are very often imperial identities.

Thus, it was not only through primary products, like tea, that this circulation of subjectivities and imaginaries was produced. As contemporary studies on the history of science (Raj 2006) and Indian colonisation (Cohn op. cit.) show, modern science, allegedly European, is the result of a multi-sited fabrication between the so-called 'West' and 'East'. The birth of disciplines like botany and astronomy, such works argue, is inseparable from the dialogues between European and South Asian scientists in situ. On the other hand, and contrary to the now widespread idea, Orientalism is much more than the making of a barbaric and uncivilised Other, as it was founded on an admiration for once glorious and culturally elevated civilisations. Besides its imperial usage and presumptuous prejudice, Orientalism therefore, was also driven by wonder at certain civilisations that, from an Orientalist point of view, suffered from the decline that led them to a tardy civilisational inferiority. What is important to apprehend from these narratives is the fact that 'European' science fed immensely on such advances and was constructed not only in 'European' centres, but also in the colonial territories in dialogue - if not in partnership - with local intellectuals; even though the appropriation carried out in Europe was so anthropophagic that the history of this joint construction was completely erased.

30 As argued in her bilingual book Borderland/La Frontera: "And if going home is denied me then I will have to stand and claim my space, making a new culture - una cultura mestiza - with my own lumber, my own bricks and mortar and my own feminist architecture' (Anzaldúa 1987: 22). 
It is evident that the trajectories present in this work, of Indian scholars living in Europe, are the result of such historical, class, gender, and caste relations, highly specific to the circulation space to which I refer. Moreover, they need to be analysed through sufficiently effective tools in order to identify privileges associated with the social positions occupied by such individuals both in India and in the global space of academic circulations - even though privileges in the global context are more fragile, given the accelerated precarity of the scientific career that is now legitimated through the idea of 'mobility'. However, it seems to me that the challenge associated with understanding the formation of such trajectories more closely approximates the efforts of authors like Stuart Hall, who seek a productive and positive understanding of such complexities, than arguments inhabited by the ghosts of moralism, or even theory that is content with notions like hybridism.

\section{Final considerations: return to India?}

By way of conclusion, I would like to mention the possibility expressed by my interlocutors to return, in some undefined future, usually after retirement, to India. Many of those now established mention this project, while seeming to recognise that the concrete conditions for such are difficult in today's circumstances: children of school age, European partners who are unlikely to move to India, or Indian couples who would need 'dual career prospects', in which both are offered permanent positions. Even those who consider leaving only after retirement must face complicating factors, such as a European spouse who has no plans to move or even the rise of the aforementioned conservative Hindu policies. This view is corroborated by the fact that few among those already retired - and, therefore, historically the first to have undergone such movement of professional mobility to Europe - have effectively returned to India.

Here, too, not only class, but particularly gender, carry great weight in understanding such projects. Some of the rare interlocutors from castes and lower classes argued that leaving India was essentially linked to the difficult living conditions for those who do not belong to the most privileged strata of Indian society. One of my interlocutors clearly said that her departure for the United Kingdom was a way of leaving behind situations of violence that low caste, 'dark skinned ${ }^{31}$ women suffer from daily in India. When asked about the possibility of returning, her response was: 'the UK is home'. This researcher does not romanticise her memories concerning India, which are marked by 'challenges' linked to the intersection of gender, caste and class. Similarly, some of my interlocutors recognised that belonging to a higher caste and to a middle class family turned out to be a kind of 'shield' that had the effect of minimising sexist experiences and gender discrimination.

I cannot explore such articulations in more detail here, but what is important is that the prospect of return inevitably depends on the positionality of such individuals in this vast space connecting the United Kingdom and India. To the extent that the project of returning proves to be very unlikely, for numerous reasons, and rarely comes to fruition, it seems to be a virtual space in which one of their feet can remain well grounded. This option seems like an open window to a backyard, through which you can look and see your own, intimate landscape, which allows you to cultivate for yourself a little of that left behind ${ }^{32}$ and what it would mean to return after building an international life.

Finally, I would like to emphasise that ordinarily India imposes itself as a mandatory theme and research field on these researchers, though rarely explicitly (Ferreira 2017b). The narrative of one of the researchers interviewed shows how this epistemic geography is delineated along these trajectories. After many years working on topics unrelated to India, which is quite rare among my interlocutors, he said that he could "return to South Asia" in his postdoctoral position, since he was setting up a new project, this time on the history

\footnotetext{
31 See footnote 2.
}

32 See Ghosh (1989) for a similar interpretation, exploring the diaspora as an act of bringing with you these spaces that must be nurtured in the new land. 
of India. He had decided to return to South Asia through theory. Many referred to their theoretical interest in India as part of a process of constructing a cultural identity or producing an 'understanding' of their own trajectories and constitution as subjects.

It is true that there is nothing new in the fact that their choices of research topic are directly determined by personal experiences or belongings that are significant to them. The debate on subjectivities in scientific research is sufficiently old and consolidated for us to accept this as evidence. What I suggest, however, is that in the case of intellectuals who produce a career in a context of post-colonial migration, the theory itself becomes a space for the construction of belonging to circulations, narratives, historical processes and even a territory. I argue that these researchers resort to academic reflection to produce narratives that theoretically elaborate their place in the world. Particularly those who publish on topics directly related to notions of belonging, displacement and political mobilisations in the global South are engaged in reflections that not only describe worlds, but also cultivate habitable landscapes for themselves within them. Writing, representing, dismantling and reorganising India as an object of reflection are ways of continuing to construct their own place in this geographic, historical and epistemological space.

Submitted: January 26,2020

Approved: May 28, 2020

Translated by: Philip Sidney Pacheco Badiz

\section{References}

ABELES, Marc. 2012. Anthropologie de la Globalisation. Paris: Payot.

AMBEDKAR, B. R. 1945. What Congress and Gandhi have done to the Untouchables. Bombay: Thacker. . 1936. The Annihilation of Caste. New Delhi: Mulk Raj Anand Editor.

ANAND, Dibiesh. 2009. "Diasporic subjectivity as an ethical position." South Asian Diaspora, 1(2): 103-111.

ANANTHAMURTY, U. R. 2012 [1976]. Samskara. A rite for a dead man. New Delhi: Oxford University Press.

ANZALDÚA, Gloria. 1987. Borderlands/La Frontera. The new mestiza. San Francisco: Aunte Lute Books.

APPADURAI, Arjun. 1996. Modernity at Large. Minneapolis: University of Minnesota Press.

ASSAYAG, Jackie; BENEÏ, Véronique. 2004. At home in diaspora. South Asian scholars and the West. New Delhi:

Permanent Black, Indiana University Press.

BACCHETTA, Paola. 2005. "Hindu nationalist women as ideologues.” In: Christophe Jaffrelot (ed.), The Sangh Parivar: A Reader. New Delhi: Oxford University Press. pp. 108-147.

. 1994. "All our goddesses are armed. Religion, resistance and revenge in the life of a militant Hindu nationalist woman." In: Kamla Bhasin, Nighat Khan and Ritu Menon (eds.), Against all odds. Essays on women, religion and development from India and Pakistan. New Delhi: Kali for Women. pp. 133-156.

BARROS, Denise Dias; AG ADNANE, Mahfouz. 2017. "Da Madraça à Universidade: itinerários de jovens tamacheque no Egito." Revista Cadernos de Campo, 23: 75-99.

BAYLY, Susan. 2007. Asian voices in a postcolonial age: Vietnam, India and beyond. Cambridge: Cambridge University Press. 
. 1999. Caste, Society and Politics in India from the Eighteenth Century to the Modern Age. Cambridge:

Cambridge University Press.

BÉNÉİ, Véronique. 2008. Schooling Passions. Nation, History, and Language in Contemporary Western India .

Stanford: Stanford University Press.

. 2005a. "Nations, diaspora and area studies. South Asia, from Great Britain to the United States." In:

Jackie Assayag and Véronique Bénéi (eds.), Remapping knowledge. The making of South Asian Studies in

India, Europe and America (19th-2oth centuries). Delhi: Three Essays Collective. pp. 53-96.

. 2005b. "L'Inde à l'étranger. Imaginaire, diasporas et nationalités." L'Homme, 1(173): 177-185.

BETEILLE, Andre. 1990. "Race, Caste and Gender." Man, New Series, 25(3): 489-504.

BHABHA, Homi. 1994. "The commitment to theory.” In: The location of culture. New York: Routledge.

pp. 28-56.

BOURDIEU, Pierre. 1980. Questions de Sociologie. Paris: Les Éditions de Minuit.

BOURDIEU, Pierre ; PASSERON, Jean-Claude 1964. Les héritiers. Les étudiants et leurs études. Paris:

Les Éditions de Minuit.

BOURDIEU, Pierre ; SAINT-MARTIN, Monique de. 1976. "Anatomie du gout." Actes de la recherche en sciences sociales, $2(5): 2-81$

BRUBAKER, Roger. 2005. «The 'Diaspora' Diaspora.» Ethnic and Racial Studies, 28: 1-19.

CHATTERJEE, Partha. 2002. Social Science research capacity in South Asia. A report. New York: Social Science Research Council.

CICCHELLI, Vincenzo. 2012. L'esprit cosmopolite : voyages de formation des jeunes en Europe. Paris: Presses de Sciences Po.

CLIFFORD, James. 1994. “Diasporas.” Cultural Anthropology, 9(3): 302-338.

COHN, Bernard. 1996. Colonialism and its forms of knowledge. The British India. Princeton: Princeton University Press.

CROUCHER, Sheila. 2012. "Privileged Mobility in an Age of Globality." Societies, 2:1-13.

DATTA, Rajat. 2016. "The Spring of 2016 and the idea of JNU." Economic and Political Weekly, 51(9): 10-13.

FERNANDES, Leela. 2006. India's New Middle Class: Democratic Politics in an Era of Economic Reform.

Minneapolis: University of Minnesota Press.

FERREIRA, Vinicius Kauê. 2017a. "Moving futures. Anthropological reflections on academic mobility and precarious life amongst South Asian social scientists in Europe." Indian Anthropologist, 47(1): 51-68. . 2017b. "Habitar o pós-colonial: notas sobre trajetórias e pertenças entre pesquisadores indianos na Europa." Ilha 19 (2): 245-276.

GARCIA, Afrânio. 2005. "Circulation internationale et formation d'une 'ecole de pensee" latino-americaine (1945-2000)." Social Science Information, 44(2-3): 521-555.

GHOSH, Amitav. 1989. “The Diaspora in Indian culture.” Public Culture, 2(1): 73-78.

HALL, Stuart. 1997. “Old and new identities, old and new ethnicities." In: Anthony King (ed.), Culture, globalization and the world-system: contemporary conditions for the representation of identity. Minneapolis: University of Minnesota Press. pp. 41-68.

. 1996. "When was 'the post-colonial'? Thinking at the limit." In: Iain Chambers and Lidia Curti (eds.), The post-colonial question. Londres et New York: Routledge. pp. 242-26o.

HANNERZ, Ulf. 1997. "Fluxos, fronteiras, híbridos: palavras-chave da antropologia transnacional." Mana, 3(1): 7-39.

KRISHNA, Sankaran. 2009. Globalization and postcolonialism. Hegemony and resistance in the twenty-first century. Plymouth, UK: Rowman \& Littlefield Publishers. 
KUMAR, Vivek. 2016. "Discrimination on campuses of higher learning. A perspective from below." Economic and Political Weekly, 51(6): 12-15.

LAHIRE, Bernard. 1995. Tableaux de famille. Heurs et malheurs scolaires en milieux populaires. Paris: Gallimard, Le Seuil.

LARDINOIS, Roland. 2007. L'invention de l'Inde. Entre ésotérisme et science. Paris: CNRS Editions.

MALKKI, Liisa. 1992. "National Geographic: the rooting of peoples and the territorialization of national identityn scholars and refugees." Cultural Anthropology, 7(1): 24-44.

MARCUS, George E. 1995. "Ethnography in/of the world-system: the emergence of multi-sited ethnography." Annual Review of Anthropology, 24: 95-117.

MIGNOLO, Walter. 1995. “Occidentalización, imperialismo, globalización: herencias coloniales y teorías postcoloniales." Revista Iberoamericana, LXI(170-171): 27-40.

O'HANLON, Rosalind. 2014. At the edges of Empire: essays in the Social and Intellectual History of India. Delhi: Permanent Black.

PEIRANO, Mariza. 2004. "Pecados e virtudes da antropologia. Uma reação ao problema do nacionalismo metodológico." Novos Estudos CEBRAP, 69: 49-56.

PHILIPS, C.H. 1967. "Modern Asian Studies in the Universities of the United Kingdom." Modern Asian Studies, 1(1): 1-14.

RAJ, Kapil. 2006. Relocating modern science. Circulation and the construction of knowledge in South Asia and Europe, 1650-1900. Delhi: Permanent Black.

RAO, Ranga. 1991. "From Chatterjee to Chatterjee." Indian Literature, 34(4): 103-111.

RIBEIRO, Gustavo Lins. 2008. “Post-imperialism. A Latin American cosmopolitics.” In: Peter Birle, Sérgio Costa and Horst Nitschack (eds.), Brazil and the Americas: convergences and perspectives. Madrid/Frankfurt: Iberoamericana/Vervuert. pp. 31-50.

RIBEIRO, Gustavo Lins; ESCOBAR, Arturo. 2006. World Anthropologies: disciplinary transformations within systems of power. Oxford: Berg.

ROY, Tirtankar. 2000. The Economic History of India - 1857-1947. Delhi: Oxford University Press.

SHARMA, K. L. 2016. "Why India Needs JNU.” Economic and Political Weekly, 51(23): 7-8.

SRIVASTAVA, Sanjay. 2013. Sexuality Studies . New Delhi: Oxford University Press.

. 1998. Constructing Post-colonial India: National Character and the Doon School . London and New York: Routledge.

. 1996. "Modernity and post-coloniality. The metropolis as metaphor." Economic and Political Weekly, 31(7): 403-412.

SUBRAHMANYAM, Sanjay. 2015. Leçons indiennes. Itinéraires d'un historien - Delhi, Lisbonne, Paris, Los Angeles. Paris: Alma Editeur.

TÖLÖLYAM, Khachig. 2007. "The contemporary discourse of Diaspora Studies." Comparative Studies of South Asia, Africa and Middle East, 27(3): 641-655. . 2005. "Restoring the logic of the sedentary to Diaspora Studies." In: Lisa Anteby-Yemini, William Berthomière and Gabriel Sheffer (eds.), Les diaspora: 2000 ans d'histoire. Rennes: Presses Universitaires de Rennes. pp. 137-148.

TEJADA, Gabriela; BHATTACHARYA, Uttam; KHADRIA, Binod; KUPTSCH, Christiane. 2014. Indian Skilled Migration and Development: To Europe and Back . New Delhi: Springer.

THUBAUVILLE, Sophia. 2013. "Indian academics in Ethiopia: south-south migration of highly skilled Indians." Diaspora Studies, 6(2): 123-133.

TRAUTMANN, Thomas R. 1997. Aryans and British India. Berkeley/London: Univ. of California Press. TRIVEDI, Harish. 1991. “The St Stephen's factor.” Indian Literature, 34(5): 183-187. 
VAN DER VEER, Peter; LEHMANN, Hartmut. 1999. Nation and religion: perspectives on Europe and Asia. Princeton: Princeton University Press.

VELHO, Gilberto. 1986. Subjetividade e sociedade: uma experiência de geração. Rio de Janeiro: Editora Zahar.

WASHBROOK, David. 2013. "Brain drain, exchange and gain: 'high-skill' migrants and the developed economies." In: Joya Chatterji and David Washbrook (eds.), Routledge Handbook of the South Asian Diasporas. New York et London: Routledge. pp. 251-26o.

WRIGHT, Susan. 2016. "Universities in a knowledge economy or ecology? Policy, contestation and abjection." Critical Policy Studies, 10(1): 1-20.

. 2014. "Knowledge that counts. Points systems and the governance of Danish universities." In: Dorothy E. Smith Alison I. Griffith (eds.), Under new public management: institutional ethnographies of changing front-line work. Toronto: University of Toronto Press. pp. 294-338.

Vinicius Kauê Ferreira

Graduate Program in Social History, Federal University of Rio de Janeiro (PPGHIS-UFRJ), Brazil

Post-doctoral scholarship granted by the Coordenação de Aperfeiçoamento de Pessoal de Nível Superior (CAPES-Brazil) (File Number: 88887.463628/2019-00).

https://orcid.org/oooo-0001-9925-3304

Email:vinikau@gmail.com 